\title{
Marco Goldoni
}

\section{The Materiality of Political Jurisprudence}

$\mathrm{T}$ he contribution Foundations of Public Law makes to the development of contemporary constitutional thought is open to multiple interpretations ${ }^{1}$. Its core concerns cover different layers of the current constitutional discourse. In fact, it is clear that Foundations is simultaneously a work of constitutional history, theory, doctrine and comparative law. In fact, one might easily adapt its theoretical insights into comparative analysis or its historical parts into an analysis of the evolution of contemporary constitutionalism. Overall, it is practically impossible to disentangle each layer without missing many of its nuances. So, even when discussing the key methodology of political jurisprudence, it is difficult to separate it from the rest of the book and its impressive breadth ${ }^{2}$. This qualification is a preliminary note necessary to explain that the criticism of political jurisprudence advanced here will have to be tested against the background of Loughlin's numerous engagements with different constitutional experiences and theories.

This article's aim is two-fold: first, to read political jurisprudence as a way of remedying the deficiencies of existing scholarship within the tradition of political constitutionalism. Political jurisprudence offers a political approach to constitutional studies which is distinctive ${ }^{3}$. Second, it will be suggested that in the prevalence of formal right ordering over processes of subjectivation, Loughlin's analysis prioritises the symbolic over the material dimension of constitutional development. A material critique of political jurisprudence will then be sketched out, but with the caveat that there are many resources, within Foundations itself, which actually allude to a material conception of public law. In fact, political jurisprudence can accommodate a material reading of the modern constitution.

\footnotetext{
${ }^{1}$ And, in general, of Loughlin's work (see also, at least, Public Law and Political Theory, Oxford, Oxford University Press, 1992; Sword and Scale, Oxford, Hart, 2000; the Idea of Public Law, Oxford, Oxford University Press, 2003).

${ }^{2}$ One might say, also from the other works by Loughlin. In general, a discussion on political jurisprudence cannot be separated from the idea of political right and to the conception of key tenets of the constitutional discourse such as State, constitution, power, authority, freedom, and government. Some of them will be highlighted below in other footnotes.

${ }^{3}$ As it will become apparent in the following analysis, political jurisprudence offers a leverage point also to comparative constitutional studies.
} 


\section{Methodology: The PRUdential RATionality OF POLITICAL JURISPRUDENCE}

Political jurisprudence is an understanding of the relation between politics and public law with a specific history (mostly modern) and a clear jurisdiction (discourses of political right around the constitution of the State). The core of its approach to the study of public law is discussed in chapter 6 of Foundations, as the concluding section of the book titled «Formation» (implied: of public law). Its genesis is contextual and genetically tied to the idea of political right or droit politique. Its field of knowledge ${ }^{4}$ is not (only) positive law, but the undergirding governmental order and its political space. More specifically, the discourse of political right «takes shape as a set of rules, principles, canons, maxims, customs, usages and manners that condition, sustain, and regulate the activity of governing the State $^{5} \gg$.

As an approach, the study of political jurisprudence is not therefore a subgenre of legal positivism and Loughlin makes this clear on several occasions ${ }^{6}$. Legal positivism expels questions of concrete order and symbolic representation underlying the legal system. It leaves the so-called «laws of governmental ordering " (as Loughlin calls them) to another domain of knowledge, outside of juristic inquiry. In contrast, political jurisprudence calls for a prudential and holistic analysis of constitutional orders. This is demanding for the constitutional scholar. As a prudential method, political jurisprudence is a historical and practical reflection on the ordering functions of public law, that is, its autonomous governing capacity. Both dimensions (historical and practical) are necessary because the emergence of an autonomous sphere of public law is the outcome of a series of historical conditions: 1) the end of a transcendental form of auctoritas which implied that what previously was an external or transcendental source of authority is now socially internalised through self-actualization; 2) the State becomes, between the $\mathrm{XVI}^{\text {th }}$ and the XVII ${ }^{\text {th }}$ centuries, the place of sovereignty (hence: «the concept of the state is nothing less than the sine qua non of public law » [183]); 3) but since the paths to the formation of an autonomous public law are context-dependent, giving rise to a plurality of discourses of political right, public law is local knowledge. In fact, as chapters 4 and 5 of Foundations show, many different accounts of the science of political right have been offered in the history of modern political philosophy. What that dense excursus reveals is that any definitive and objective interpretation of political right is vain and, by definition, impossible. The knowledge of political jurisprudence is practical because it is always an internal reflection on (to stick to Loughlin's terminology) the «grammar» and the «architecture » of the practice itself and on the

\footnotetext{
${ }^{4}$ See P. Bourdieu, The Logic of Practice, Stanford, Stanford University Press, 1990, p. 59.

5 p. 11.

${ }^{6}$ For example, « if the objective is to apprehend the legal order as something inherently rational, then legal positivist methods are altogether inadequate » (p. 159).
} 
presumptions which anchor them. It is also an unstable form of knowledge, because it has to negotiate between the polarities of a bifurcated discourse.

Again, the political jurisprudent faces a situation of deep ambiguity. On one hand, public law is a juristic enterprise requiring, at the very least, a theory of the source of the authority of the laws that establish the State and the institutions of its self-actualisation; on the other hand there is no Archimedean point « from which objective authority can be determined ${ }^{7} »$. To cope with this tension (potentially fatal for the scientific status of the discipline), political jurisprudence strikes a cautionary note. It reminds us, first, that «the relationship between theory and practice is... of such complexity as to render any general account of the emergence of modern public law both partial and provisional ${ }^{8} »$. Second, political jurisprudence begins with the recognition that there are multiple, partial accounts of political right. This means that the task of political jurisprudence is not to provide a general theory of public law. On the contrary, the task of political jurisprudence is «to negotiate between the various conflicting accounts of political right that form part of its evolving discourse ${ }^{9} »$. Loughlin's extension of the scope of public law to encompass the negotiation of competing conceptions of political right is not to deprive public law of its juristic quality or to transform it into an exercise in moral or political reasoning ${ }^{10}$. The idea of public law germane to political jurisprudence is one of «an immanent practice that conditions and sustains the activity of governing » and which «incorporates no transcendental or metaphysical ideas of justice and goodness: it is concerned solely with those precepts of conduct that have evolved though political practice to ensure the maintenance of the public realm as an autonomous entity ${ }^{11} \gg$. Public law has a distinctive role in generating and sustaining institutional authority in an autonomous political realm and its nature makes it essential to engage with political jurisprudence. Understanding the foundations of public law is critical because public law is a discourse where concepts such as governing, sovereignty and representation are organised and combined in order to establish the autonomous sphere in which public power can effectively operate $^{12}$.

It is crucial to remember that this conception of public law is not meant to convert it into the pursuit of a (impossible) science of political right. The rationality of political jurisprudence is grounded on prudential considerations, so that it is more about «negotiating» than reconciling or eliminating tensions between the polarities of public law. The negotiation

${ }^{12}$ See M. WALters, «Is Public Law Ordinary? », Modern Law Review, 75, 2012, p. 912, for a critique of the claim that public law is autonomous.
} 
itself, we are told, is the exercise rather than the explanation of prudential judgment ${ }^{13}$. In this respect, the core of political jurisprudence's methodology is hermeneutical. Rather than seeking to separate facts and values, Loughlin adopts an interpretative method to develop his approach. Once a field of investigation is identified, the task for the political jurisprudent is to reconstruct the discourse of its subjects with « a search for coherence » which derives from «a common pattern of meaning shared amongst these subjects ${ }^{14} »$. When looking for the content of public law, the "assumption that there are indisputable facts in this field that can be acquired by objective empirical investigation is erroneous: we are constantly seeking to fit this evidence to our pre-existing assumptions about the subject $^{15} \gg$ The main core of this approach is interpretation: indeed, when we are concerned about meaning «we are always interpreting ${ }^{16}$ ». If hermeneutics is political jurisprudence's epistemology, its legal philosophy is a form of institutionalism capable of finessing the relation between normativity and facticity ${ }^{17}$. As we shall see below, this is functional to the reconstruction of modern public law based on the distinction between potentia and potestas. In light of the previous remarks, it should be evident that Loughlin's institutionalism does not share the normative assumptions undergirding Neil MacCormick's type of institutionalism ${ }^{18}$. On the contrary, it retrieves an understanding of legal institutionalism indebted to Schmitt's turn to concrete order thinking ${ }^{19}$ and to an LSE tradition heavily influenced by French legal institutionalism ${ }^{20}$. In particular, Loughlin's reading of the LSE functionalists (Laski, Robson, Jennings) emphasises their institutionalist background and is rather original because it downplays their legal positivism in favour of the juristic qualities of their constitutional thought $^{21}$. The argument will now be made that political jurisprudence is a new chapter in this history of constitutional thought.

\footnotetext{
${ }^{13}$ See, also, the remark that public law is « a form of political reasoning driven by prudential considerations » (M. Loughlin, The Idea of Public Law, op. cit., p. 163).

${ }^{14}$ M. Loughlin, «Theory and Values in Public Law: An Interpretation », Public Law, 2005, p. 61.

15 Ibid., p. 63.

${ }^{16}$ Ibid.

${ }^{17}$ See Loughlin's recent chapter on nomos in D. DyzEnHaus \& T. PoOLE (eds), Law, Liberty and the State: Hayek, Oakeshott and Schmitt on the Rule of Law, Cambridge, Cambridge University Press, 2015, p. 65-95.

${ }^{18}$ See N. MACCORMICK, Institutions of Law, Oxford, Oxford University Press, 2007.

${ }^{19}$ C. Schmitt, On the Three Types of Juristic Thought, New York, Praeger, 2004

${ }^{20}$ A classic example of this influence is visible in the collection Modern Theories of Law, Oxford University Press, Oxford, 1930, where a chapter by Laski is devoted to Maurice Hauriou and one by Jennings to Duguit. It is also important to note that Laski translated Duguit's classic: Les transformations du droit public (1913).

${ }^{21}$ For an intriguing attempt at reconciling political jurisprudence with one particular version of legal positivism (normative positivism) see M. GORDON, «A Basis for Positivist and Political Public Law: Reconciling Loughlin's Public Law with (Normative) Legal Positivism », Jurisprudence, 6, 2015, forthcoming. Gordon makes an interesting point
} 


\section{TRAJECTORY: FROM A FUNCTIONAL TO A REFLEXIVE POLITICAL JURISPRUDENCE}

The previous remarks on Loughlin's institutionalism can help trace the trajectory of his approach. Political jurisprudence is a way of framing the knowledge of public law and as such it addresses a concern already present in the work of John Griffith. Griffith is rarely invoked in Foundations and his dismissal of the State as metaphysical nonsense is firmly rejected by Loughlin at the outset of the book ${ }^{22}$. Yet, Foundations is dedicated to Griffith and, at a closer look, it seems indebted to his tradition in two ways. The first is that political jurisprudence is a way to respond to Griffith's appeal for a renewal of constitutional scholarship advanced as early in the 1960 's in an article entitled «Why we need a revolution ${ }^{23}$ » Political jurisprudence as the prudential science of political right is offered as a more solid and refined approach to constitutional studies. Actually, one might read political jurisprudence as a vindication of the necessity to understand the constitution beyond its formal appearance as suggested by Griffith $^{24}$. Except that, contrary to Griffith, Loughlin's concrete order thinking cannot dismiss the State as a metaphysical construct. Bringing back State sovereignty into the picture is a way of going against Griffith with Griffith.

The consequences of such a renewal of constitutional scholarship are multiple and varied. This brings us to the second rather clear link to Griffith's work and, more generally, to the recently debated tradition of the political constitution. Loughlin gives a particular reading of the idea of the political constitution by enlarging the scope of the inquiry to include the continental traditions of constitutional thought and by placing the reflection on the British constitution within the dynamics of the development of European States ${ }^{25}$. This time one might say that political jurisprudence interprets public law in a manner that avoids the pitfalls of the previous conceptions of the political constitution, but at the same time redeems some of the intuitions of its first functionalist phase. In other words, to adopt Loughlin's register, political jurisprudence can be read as an attempt at remedying the shortcomings of the first two waves of functional and then

\footnotetext{
based on the normative concept of law endorsed by Waldron and Campbell, stating that this is compatible with political jurisprudence.

${ }^{22}$ In a recent article, Loughlin proposes to read the famous article on the political constitution as the swan song of functionalism, that is, the eulogy of a constitution that was no longer: « Modernism in British Public Law: 1919-1979 », Public Law, 2014, p. 56-67.

${ }^{23}$ J. GRIFFITH, «Why We Need a Revolution? », Political Quarterly, 40, 1969, p. 383 sq.

${ }^{24}$ The iconic reference is J. GRIFFITH, «The Political Constitution », Modern Law Review, 42, 1979, p. 1-22. On this influential piece see, at least, G. GEE, «The Political Constitutionalism of John Griffith», in Legal Studies, 28, 2008, p. 20-45; T. Poole, «Tilting at Windmills? », Modern Law Review, 70, 2007, p. 250 sq.

25 This plan is stated clearly at the outset of the book: «In order to address these foundational questions, the British are obliged to re-connect with the mainstream of the European tradition of public law » (p. 6).
} 
normative political constitutionalism ${ }^{26}$. In fact, political jurisprudence offers a new take on public law studies and it is at the forefront of an incipient «third wave » of political constitutionalist scholarship ${ }^{27}$.

At this point, some clarification is necessary. A first wave of political constitutionalist studies can be traced back to an arch spanning, roughly, from Jennings' major works in the 1930's to Griffith's famous Chorley lecture $^{28}$. The main thrust of this trend is to revert the classic liberal normativism of the Diceyan school, based on individualism and on the necessity of constraining an increasingly invasive government. The functionalists reverted to utilitarianism and adopted an instrumental conception of public law, that is, they viewed constitutional law as a tool through which one might effect social change. From the perspective of political jurisprudence, the relationship between political power and law is trivialised because the idea of legal ordering is bypassed in favour of a conception of law as the transmission belt of political will.

From the 1990's to the present, a second «wave» of political constitutionalists has tried to overcome the limits of the functionalist approach by resorting to a normative conception of constitutional law and constitutionalism. That enquiry has become highly idealised and often abstracts from the concrete relations of power between political subjects. It is also not surprising that the legal theory undergirding this second wave has been normative positivism ${ }^{29}$. The concrete politicality of the constitution is lost because the State is collapsed into the government and parliamentary politics is abstracted from the dynamics of parliamentary systems and political conflict. The basic intuition behind the second wave is that parliamentary sovereignty needs a stronger normative (rather than functional) justification and in order to provide for that, political constitutionalists accept the basic premise of liberal normativism: the individual as the main unit of constitutional analysis ${ }^{30}$.

The premises upon which this second wave is built are famously known as the two circumstances of politics: that human beings disagree (Hannah Arendt would say that the human condition is marked by plurality) and that they need to reach a decision on common problems ${ }^{31}$. Reasonable

\footnotetext{
${ }^{26}$ For a reconstruction of functional political constitutionalism, See M. LoUGHLIN, Public Law and Political Theory, Oxford, Oxford University Press, 1992, chapter 6.

${ }^{27}$ See, for a similar project, G. GEE \& G. WEBBER, « Rationalism in Public Law », Modern Law Review, 76, 2013, p. 708-734.

${ }^{28}$ I. Jennings, Cabinet Government, Cambridge, Cambridge University Press, 1936; id., Parliament, Cambridge, Cambridge University Press, 1938.

${ }^{29}$ See, e.g., J. WALDRON, Law and Disagreement, Oxford, Oxford University Press, 1999; T. CAMPBELl, The Legal Theory of Ethical Positivism, Burlington, Ashgate, 1996; R. Bellamy, «Political Constitutionalism and the Human Rights Act», International Journal of Constitutional Law, 9, 2011, p. 86-111.

${ }^{30}$ This is one of the main accusations made by Jennings to Dicey: see The Law and the Constitution, London, University of London Press, 1963.
}

${ }^{31}$ J. WALDRON, Law and Disagreement, op. cit., p. 102. 
disagreement is the originating phenomenon to which the political constitution is supposed to respond. The resilience of parliamentary sovereignty is supposed to accommodate this type of disagreement. The political constitution offers «a site for discussion and debate, and the reconciliation of conflict. It is a recognition that everyone matters, that there is no monopoly of wisdom on ideas, and that differences can be reconciled in a deliberative assembly. It can accommodate the politics of both post-war socialism and modern-day neo-liberalism ${ }^{32} »$. As a consequence, in this normative version, political constitutionalism takes the formal approach of recognising individual disagreement and channelling it either through political accountability (Tomkins) or representative law-making (Bellamy, Waldron, Ewing and Campbell).

But this stream of political constitutionalism is in danger of surrendering to empty abstractions (parliament, government, accountability) and remaining blind to the layers of material complexity throughout the political constitution ${ }^{33}$. Most importantly, this normative wave of political constitutionalism does not draw any analytical distinction between the State and the government. As a consequence, the question of the generation and preservation of political power is blurred and questions of individual rights protection take precedence.

Political jurisprudence offers precious insights to overcome the drawbacks of these normative efforts and to redeem some important functionalist arguments. A first crucial difference is that the politics/law nexus is seen through an analysis of the political formation of the modern State. Applied to parliamentary sovereignty, for example, this means an inquiry into the historical and factual conditions undergirding it. In the case of the UK constitution (usually singled out as the classic model of the political constitution), the reason why parliament occupies such a central place in the constitutional imagination is because it has represented the institutionalisation of the political unity of England (then extended to the other nations). Loughlin calls this process the formation of the «parliamentary State ». The reason it endured is that it represented, through a series of reforms (financial, military and administrative), the most powerful State-building force ${ }^{34}$. The conclusion is that parliamentary sovereignty cannot be explained away by referring to normative arguments, but it has to be analysed and understood as the outcome of a concrete process of organising the constitutional imagination within a specific jurisdiction. The State provides the spatial and temporal matrix for the organisation of the legal order, but its form is determined by different prudential factors.

\footnotetext{
${ }^{32}$ K. EwING, «The resilience of the Political Constitution », German Law Journal, 13, 2013, p. 2099.

${ }^{33}$ For a similar criticism, this time concerning the use of constitutional language, see G. GEE \& G. WeBber, «A Grammar of Public Law », German Law Journal, 14, 2013, p. 2137-2155.

${ }^{34}$ M. Loughlin, The British Constitution, Oxford, Oxford University Press, 2013.
} 
This last point introduces a second crucial difference, which is that the State and the government are not conflated or confused in political jurisprudence. The State is presented as a scheme of intelligibility ${ }^{35}$, which makes it possible to identify the relevant relations between the state and governmental apparatus. The political constitution is not therefore reduced to a single relation between government and the individual or to institutional questions of the protection of rights. Political jurisprudence avoids these narrow concerns precisely because it does not sever law from politics. Indeed, one of the greatest insights of political jurisprudence is its retrieval of juristic knowledge of State-building and State transformation. This type of juristic knowledge demands a step back from the exclusive focus on government and the «restoration» of fundamental laws as its main concern $^{36}$. From the perspective of political jurisprudence, the critical flaw of the legal positivism that informs the second wave of political constitutionalism is that it detaches from juristic inquiry consideration of those aspects of political right which are manifest in the operation of constitutional orders. The influence of this kind of legal positivism has been such that «by foregrounding the question of validity (is this or is this not a rule of an extant legal order?), modern jurisprudence has tended to push issues of authority to its periphery ${ }^{37} »$. All the foundational concepts of public law enabling the activity of governing are marginalised in this tradition of thought.

Public law as political jurisprudence is crafted by employing a methodology rooted in the assumption that the object of the discipline can « have meaning only within a field (that is, in relation to other things) ${ }^{38}$ ». Applied to political jurisprudence, the «assumption that there are indisputable facts in this field that can be acquired by objective empirical investigation is erroneous: we are constantly seeking to fit this evidence to our pre-existing assumptions about the subject ${ }^{39} \gg$. In fact, understood from the perspective of juristic knowledge, public law can only be conceived as local knowledge: «the relationship between theory and practice is, in short, of such complexity as to render any general account of the emergence of modern public law both partial and provisional ${ }^{40} \gg$. In other words, mapping

\footnotetext{
${ }^{35}$ P. Steinberger, The Idea of the State, Cambridge, Cambridge University Press, 2004, p. 25.

${ }^{36}$ Loughlin is very clear about the difference with classic legal positivism: « a clean break cannot be effected between the ancient and modern ideas of the constitution and [...] the modern attempt to focus purely on the constitution of the office of government provides no substitute for reflection on the constitution of the state [...] Only by restoring a public law perspective, by viewing the constitution as an exercise in statecraft that functions according to the precepts of droit politique, will it be possible adequately to address the fundamental issue » (pp. 310-311).

${ }^{37}$ p. 10 .

${ }^{38}$ M. Loughlin, «Theory and Values in Public Law: An Interpretation », Public Law, 2005 , p. 61.

${ }^{39}$ Ibid., p. 63.

${ }^{40}$ p. 158.
} 
the knowledge of public law entails, at most, only historical a priori (the modern state being the main reference for modern constitutions) whose texture is given by family resemblances ${ }^{41}$.

Once brought into this debate, political jurisprudence provides an added value, which is later characterised by Loughlin in terms of the reflexivity of constitutionalism $^{42}$. One of the goods offered by political jurisprudence is epistemic: «by placing modern constitutions within the frame of droit politique, the critical dynamic between the constitution (the text) and constitutionality (the process whereby the text comes to play an increasingly important role in the regulation of the political sphere) is revealed ${ }^{43} »$. Political jurisprudence unveils several aspects of the relational nature of public law: the conditional authority of the constitution, the moment of foundation as a post-hoc rationalization, the relational nature of constituent power $^{44}$, the symbolic role played by constitutions as forces of stability in the shaping of political and national identity, to name just a few.

And yet, despite all the emphasis on the process rather than the event in the institutional configuration of authority one aspect seems to remain neglected in Foundations: the role of subjects and their subjectivation in the formation and development of modern constitutions. Before moving to examine it, a brief detour on the idea of right ordering is necessary to preparing a possible explanation for this neglect.

\section{OBJECT: RIGHT ORDERING AND ITS GRAMMAR}

As remarked above, what is missing completely from the perspective of the second, normative wave of political constitutionalism is the idea of ordering, and the distinction between droit politique and the positive law that accompanies it. The second wave of political constitutionalism ends up adopting a normative positivist view of the constitution, reducing it to a system of norms. In contrast, the main objects of analysis in political jurisprudence inhabit three distinct layers: the State, the constitution and the government. These terms also provide the entry point for understanding the forms of power generated by public law (potestats and potentia). Loughlin assumes that the point of an autonomous public law is, in modern times, to generate power and freedom ${ }^{45}$. The task for political jurisprudence is to explain how, despite competing accounts of political right, public law can

\footnotetext{
${ }^{41}$ The classic reference here is M. Foucault, The Archaeology of Knowledge, London, Routledge, 2004, p. 126-128.

42 p. $310-311$.

${ }^{43}$ P. 311.

${ }^{44}$ See M. Loughlin, «Constituent Power », European Journal of Political Theory, 13, 2014, p. 218-237.

${ }^{45}$ While they strongly disagree on the scope of public law's autonomy and, obviously, on methodology, Loughlin and Thornhill both agree that modern public law generated (and not just limited) huge amount of political power.
} 
manage and govern the ambiguous relation between the sovereign State and the freedom of the subject, or, in other words, between power and liberty. In short, and at risk of oversimplification, both terms ought to be understood as « correlative $e^{46} »$. Power is defined as twofold: structural and infrastructural, potentia and potestas. Liberty, far from being negative freedom, is also an ambivalent notion, fully inscribed within the operation of political power ${ }^{47}$.

In terms of constitutional theory, the main insight offered by these observations is that power and liberty are not pre-political, but created by public law itself: more precisely, «power and liberty are created through the operation of the practices of public law ${ }^{48} \gg$. Within the field of public law, one cannot exist without the other, but also, critically, one cannot become synonymous with the other. The efficient core of public law lies precisely in the maintenance of a productive tension between these polarities. Political jurisprudence, by managing these tensions, is meant to rationalise the " art of governing » developing a prudential discourse that doesn't dissolve or blur the distinctions.

At this level of discourse, a critical point for the deployment of political jurisprudence is reached; it is a point where the methodological difference between the normative and the reflexive understanding of constitutionalism is at its greatest. As already noted, the issue of the generation of power is not registered by normative constitutionalists. Political jurisprudence makes an astute move here because it commits to the ambiguity of political power: once political power is understood as emerging internally from society and then necessarily managed without any reference to a transcendental source, public law (as the architecture of political power) can absorb society and condition citizens' freedoms. Here lies also the immanent ambiguity of public law: public law is constitutive of power and freedom but the art of governing can potentially absorb society and becoming a dangerous activity.

As already noted, the main concern behind the enterprise of political jurisprudence is to secure the protection (and intelligibility) of the constitutional order through prudential judgments. Endorsing Meinecke's analysis of the reasons of State, Loughlin argues that for political jurisprudence the main value is represented by the well-being of the State and «power, maintenance of power, extension of power, is the indispensable means which must [...] be procured ${ }^{49} \gg$. Right ordering, as the coupling of the power to rule and the right of rule, is an essential tenet of this process of power formation ${ }^{50}$. Political jurisprudence provides the grammar for understanding it qua practice.

\footnotetext{
${ }^{46}$ p. 178.

47 A key reference here is provided by H. ARENDT, The Human Condition, Chicago, Chicago University Press, 1958, chapter V.

${ }^{48}$ Ibid.

${ }^{49}$ Quoting from Meinecke, p. 87.

${ }^{50}$ On this point there are many affinities between Loughlin's account of right ordering and Hans Lindahl's. Loughlin himself has noted these similarities: "A-legality or Jus
} 
Despite his many claims that the edifice of public law is based on prudential grounds, there seems to be a lot going on in Loughlin's use of metaphorical terms such as « architecture ${ }^{51}$ », «framework », «grammar », «code», - all concepts suggesting structure and stability. Much less attention is devoted to subjectivity. Once one might have said: organisation has the upper hand, subjectivity is marginal ${ }^{52}$. In fact, political jurisprudence greatly emphasises the grammar of the practice of public law. Focussing on the grammar of public law allows us to unveil the double dimension of constitutive rules: "they are the rules that we have devised [...] for the correct use of certain terms » and they are based on certain background assumptions $^{53}$. This means that they operate both as enabling and limiting rules. The meaning of the latter is conditioned by their peculiar grammar.

The grammar of public law reminds us that public law is local knowledge, not universal. Alternative grammars are always conceivable and available. Language itself is in constant evolution and no sovereign remains outside it ${ }^{54}$. In fact, Loughlin notes that «we acquire knowledge of the words and symbols of the language in conjunction with an understanding of the appropriate circumstances in which to use them ${ }^{55} \gg$. Intriguingly, he adds that the reconstruction of the practice of public law «must be seen to be context-dependent and purpose-relative ${ }^{56} \gg$. The meaning of a constitutional rule can be grasped only if one understands the relevant constitutional language. Crucially, in order to understand the latter, one has to be able to imagine the form of life which undergirds it.

The added value of political jurisprudence is therefore to offer a more accurate understanding of public law: «by studying the grammar we become more skilled at extending the language to cover unusual cases or situations that appear exceptional $^{57} \gg$. The grammar of public law opens juristic knowledge to a wider array of concerns, exceptions and political decisions included ${ }^{58}$. No wonder, then, that to speak of public law is equivalent to imagining a form of life that inhabits it. This configures political jurisprudence always as an internal enterprise. The fact that it is

Politicum: A Critical Appraisal of Hans Lindhal's Fault Line of Globalization », Ethics and Politics, 2, 2014, p. 965-972.

${ }^{51}$ Chapter 3 of Foundations is titled « The Architecture of Public Law ».

${ }^{52}$ M. Tront, Operai e capitale, Roma, Derive e Approdi, 2004 [1966], p. 23.

${ }^{53}$ p. 178.

${ }^{54}$ It is not clear from the text whether language is used as language or langue. The impression is that grammar and the specific instantiation of a language (how the language is spoken) are conflated by Loughlin.

${ }^{55}$ p. 179.

56 Ibid.

${ }^{57}$ p. 179.

${ }^{58}$ Mortati had already identified the juridical relevance of the exception, as reminded in M. Croce, A. SAlvatore, The Legal Theory of Carl Schmitt, Abingdton, Routledge, 2012, p. 187. 
exercised from within does not mean that it will demand constitutional reform ${ }^{59}$.

However, grammar does not fully capture a particular constitutional reality because its form is conventional. The scrutiny of political jurisprudence based on conventional rules alone does not have the capacity to represent the whole constitutional reality. Indeed, the criterion of appropriateness is linked to logical ordering rather than a substantive representation.

One might therefore ask whether grammar operates as an excessively rigid structure and, in the end, actually represents a reductive approach. After all, «we turn to grammar for an explanation of the structural features of a language $\mathrm{e}^{60} »$. But is the grammar generative of constitutional meaning analogous to the relation between language (langue) and speech (parole)? Loughlin discards the idea of a generative grammar (or Ur-grammar) and defends the virtue of having competing grammars as a way to maintain the ambiguity of public law. Yet, such a recognition is not enough to avoid the pitfalls of constitutional structuralism. The questions of how the grammar is shaped and what is its impact upon its subjects remain open. Are the identity and the role of subjects completely determined by the language of public law? It is doubtful that the study of the grammar of public law can capture all its constituent and dynamic components. If taken literally, the analogy of grammar implies the study of public law as an examination of its constitutive and performative aspects. For a theory whose idea of power is fully relational (political power is not to be found in one place, but rather it « ultimately inheres in the form which the political relationship takes $\left.{ }^{61} »\right)$, the analogy of grammar might then come across as a straitjacket rather than an enabling perspective. After all, how and where political unity is obtained are constitutional questions which cannot be wished away by postulating the epistemic necessity of sovereignty and they cannot be addressed through the perspective of grammar. The risk is that the subjects of public law are described as an effect of its grammar and all the political nuances related to their formation and development are lost.

Processes of subjectivation are far from being exhausted by constitutive and regulative rules; they are obtained through immersion in a series of relations which cannot be accessed exclusively through grammar and $\operatorname{syntax}^{62}$. For example, the political force of the main agents behind a constitutional order does not derive (at least not entirely) from the grammatical structure of public law. A grammar of public law cannot account for the non-linguistic element of political agency. It is to this material level of the determination of subjectivity that we now turn.

\footnotetext{
59 A similar approach, but more attentive to a cultural understanding of constitutional theory, is put forward by P. KAHN, The Cultural Study of Law, Chicago, Chicago University Press, 1999.

${ }^{60}$ p. 178.

${ }^{61}$ M. Loughlin, The Idea of Public Law, op. cit., p. 83.

${ }^{62}$ See M. BAKHTIN, Speech Genres, Austin, University of Texas, 1986.
} 


\section{IV.SUBJECTIVITY: THE MATERIAL CONSTITUTION}

The partial lack of focus on subjectivity betrays a residue of formalism which, or so it seems from the text, is not intended by the author. It is also quite striking that the processes of subjectivation are not taken into account given that the reconstruction of the power/liberty nexus advanced by Loughlin is much indebted to the analysis of - among others - Michel Foucault, for whom subjectivation was intrinsic to the dynamics of molecular power, in particular through various forms of resistance ${ }^{63}$.

The point made here however concerns a different level of engagement and argues that the marginal treatment of the role of subjects and subjectivation generates a "material deficit », that is, a lack of materiality, in Loughlin's analysis of both the State and its constitution. One has to be careful in order to avoid misunderstandings. This is not to argue that the lack of treatment of subjectivation can be easily remedied by resorting to the work of political philosophers such as Jacques Rancière or Alain Badiou. The advocates of a «politics of rupture » are not interested « in the question of the forms of organization of political collectives » and they do not take into consideration «the alterations produced by acts of political subjectivation $^{64} »$. Rancière (whose work provides a powerful conception of constituent power) is rather adamant in adopting a «formalist' understanding of the political. Politics is above all a question of form, a formalism of equality: "what makes an action political is not its object or the place where it is carried out, but solely its form, the form in which confirmation of equality is inscribed in the setting up of a dispute, of a community existing solely through being divided ${ }^{65} \gg$.

The point made here is rather that the role of subjects (in particular, political subjectivities) ought to be taken into account by political jurisprudence because political action forges the material constitution. In particular, juristic knowledge should not ignore the material conditioning of subjectivities within a constitutional state and, from this perspective, their contribution to right ordering (usually through political conflict, bargaining, negotiations and, last but not least, the creation of a hegemonic bloc). The issue flagged up here, then, is not that political jurisprudence does not take into account disruptive politics; this is a misplaced criticism because the main concern of political jurisprudence is right ordering. It is, rather, that every concrete legal order is supported by particular subjects, or, in constitutional jargon, political and social forces. To repeat what was stated

\footnotetext{
${ }^{63}$ M. Foucault, « The Subject and Power », in H. DREYfus \& P. RABINOW (eds), Michel Foucault. Beyond Hermeneutics and Structuralism, Chicago, University of Chicago Press, 1983, p. 327-348. At the same time, Foucault would ground subjectivation on an ethics of the government of the self: «Government of self and others ». I doubt that Loughlin would allow any kind of ethics slipping into political jurisprudence.

64 J. RANCIÈRE, «La méthode de l'égalité », in L. CORNU \& P. VERMEREN (eds), La philosophie déplacée: autour de Jacques Rancière, Lyon, Horlieu, 2006, p. 514. Rancière refuses to examine «the forms of consistency of the groups that produce them ».
}

65 J. RANCIÈRE, Disagreement, Minneapolis, University of Minnesota Press, 1999, p. 32. 
in the previous section, the particular strength of hegemonic political forces is not the result of grammatical rules.

Loughlin himself concedes that there is no single exemplary model of the modern constitutional state, but multiple experiences of it. The State exists only in its instantiations and those instantiations cannot be explained nor described by the grammar of public law. Nonetheless, it should be remembered that political jurisprudence begins from the recognition of the primacy of the material over the formal constitution. This points to five consequences affecting the study of public law: 1) the validity of the formal constitution is determined by an act of political will ${ }^{66} ; 2$ ) the validity of the formal constitution does not rest on its correctness; 3) the formal constitution is not a codification; 4) the state of exception is legitimate when it preserves the material constitution; 5) amendability of the constitution is limited by the main tenets of the material constitution ${ }^{67}$. These insights are precious for public law and for comparative constitutional law. Yet, the potential dividends of the previous points are not fully cashed out in Foundations.

In fact, the consequences of the political economy that undergirds the material constitution are not explored in full. The analysis of Sieyès' conception of the constitution illustrates this point. His famous political treatise on the Third Estate is rightly recognised as a work of political jurisprudence. But Loughlin reads too much into Sieyès' emphasis on the nation as the only authentic source of the constitution and, in the language of political jurisprudence, as the guarantor of political unity. What is missing from that analysis is the link between the material dimension of the nation and the artificial construction of the political unity (the abbé, in order to stress its artificial nature, called the latter process adunation) ${ }^{68}$.

While it is correct to highlight that Sieyès distinguishes between State and government, nation and positive law, it cannot be assumed that Sieyès' statement - «The nation exists prior to everything: it is the origin of everything. Its will is always legal. It is the law itself ${ }^{69} \gg-$ is tantamount to a recognition of the juristic distinction between constitution and constitutional law. In fact, Sieyès adds a few lines below that «A nation is formed solely by natural law $^{70} »$. Many commentators have noted that when Sieyes speaks of natural law he intends the organisation of society according

\footnotetext{
${ }^{66}$ See P. KAHN, Putting Liberalism in Its Place, Princeton, Princeton University Press, 2005, p. 303.

${ }^{67}$ p. 215.

${ }^{68}$ See P. PASQuino, Sieyès et l'invention de la constitution, Paris, Odile Jacob, 1998, p. 3335 .

${ }^{69}$ E. J. SIEYÈS, What Is the Third Estate?, in Political Writings, Indianapolis, Hackett, 2003, p. 128 .

${ }^{70}$ Ibid., p. 136-137.
} 
to its political economy ${ }^{71}$. The nation, in fact, is far from being an existential unity. On the contrary; the nation is the organisation of functions and services, as is clearly stated at the beginning of that famous tract. These public and private functions ensure the constitution and reproduction of society around certain political principles, which in case of Sieyès' constitutional thought, are the division of labour and representation. While it remains clear that Sieyès' thought operates within certain coordinates (dictated by the modern State), it is impossible, on the other hand, to understand why the constitutional order ought to take a certain form without refer to the undergirding subjects comprising the Third Estate.

Enlarging the scope of juristic knowledge to the study of the material constitution enlarges the field of public law and illuminates the concrete nature of legal orders in their different configurations. The study of the material dimension of modern constitutional orders can illustrate their specificities and peculiarities in a way that is precluded in grammatical analysis $^{72}$. Political unity is shaped according to a concrete political trajectory and supported through the creation of hegemonic blocs, usually united around the pursuit of basic political aims. As Nicos Poulantzas brilliantly reminded us, there must be a reason why the contemporary liberal state gave itself that distinctive type of political constitution rather than another one ${ }^{73}$. Following his advice, the materiality of states and constitutions ought to be reconstructed through analysing the concrete spatial-temporal matrix that establishes the conditions of visibility and relevance of political subjects in a particular time and place. Moreover, it demands analysis of why political forces gather together and converge around certain objectives.

The material constitution has an object and a function. Its function is the production of political unity, while its object is the political trajectory of the State $^{74}$. Both «operations » impact on the organisation of society and its political system. The material constitution is always organised around the pursuit of specific objectives and the strive to reach those objectives is strengthened by the formation of a hegemonic bloc whose concrete political power is supposed to leave an imprint upon society. Hence, the determination of the political trajectory of the State becomes an autonomous

\footnotetext{
${ }^{71}$ See O. BEAUD, La puissance de l'État, Paris, PUF, 1994, p. 338; C. LARRÈre, « Sieyès lecteur des physiocrates: Droit naturel ou économie ? », in P.-Y. QUIVIGER, V. DENIS, J. SALEM (eds), Figures de Sieyès, Paris, Publications de la Sorbonne, 2008, p. 195-212.

72 A fruitful example of this type of analysis, applied to the European Union, is M. WiLKInSON, «Political Constitutionalism and the European Union », Modern Law Review, 76, 2013, p. 191-222.

${ }^{73}$ N. Poulantzas, State, Power, Socialism, London, Verso, 2004, p. 104.

${ }^{74}$ I use the expression «political trajectory » to translate what Italian constitutional realists defined as «indirizzo politico». See V. CRISAFULLI, «Per una teoria giuridica dell'indirizzo politico » [1939], in Prima e dopo la costituzione, Napoli, ESI, 2015, p. 35113.
} 
and peculiar trait of the modern art of governing societies ${ }^{75}$. In other words, the materiality of the constitution is the "condensation » of social and political forces around determined objectives ${ }^{76}$. The condensation of specific forces around fixed political aims entails the creation of an institutional structure functional to the pursuit of those aims; nonetheless, the edification of this structure cannot be identified strictly with the realisation of those aims. The discrepancy between structure and function opens up a space for a relative political autonomy. Clearly, the political unity of a society is not granted once and for all, but is constantly subject to internal and external pressures. Unlike the classic understanding of the State as external to society and as a static institution, the material constitution shows the internally relational and dynamic nature of the State/society nexus ${ }^{77}$.

This is clearly relevant for juristic knowledge, for two reasons: it provides a more accurate picture of the evolution of political constitutions and regimes ${ }^{78}$, and, from the perspective of public law, it unveils the imprint behind the legal order, revealing the point of its rules from the perspective of the State's political trajectory and its governing function ${ }^{79}$.

Loughlin's understanding of the materiality of institutions and political subjects is riddled with ambiguity. He recognises that institutions (and the State as institution of institutions) are based on ideas, which confer meaning on the component parts of an institution. Ideas are not only regulative, but also constitutive. But to perform the latter function they cannot remain purely abstract. Loughlin here follows Peter Steinberger's reconstruction of the idea of the State: constituting ideas «work through the principle of necessary embodiment ${ }^{80} »$. What kind of embodiment is this? At this point, political jurisprudence is in danger of leaving the domain of concrete order and landing in the field of political theology. The embodiment could be read as requiring that ideas are literally inscribed upon the citizen's body, which would work here as the material substratum of the constitutional imagination. It is not clear whether Foundations endorses this reading of embodiment, which would resonate with Schmitt's concept of the

\footnotetext{
${ }^{75}$ Costantino Mortati identified first the governing function as the ur-function of every State in L'ordinamento del governo nel nuovo diritto pubblico italiano [1931], Milano, Giuffré, 2000.

${ }^{76}$ N. Poulantzas, State, Power, Socialism, op. cit., p. 186-187.

${ }^{77}$ See the criticisms of the State as a thing or as a subject in N. PoulantZAS, State, Power, Socialism, op. cit., p. 190-204.

${ }^{78}$ Some of the same concerns are shared by the American School of Constitutional Development: see S. SkowroneK, The Politics Presidents Make, Cambridge Mass., Harvard University Press, 1993.

79 The same set of rules (say, the same formal constitution), applied in two different material contexts, has different points. This is a common insight of classic legal institutionalism, either in the version of the directive idea (idée directrice) by Hauriou or, more recently, in terms of commitment by R. COVER, « Nomos and Narrative », Harvard Law Review, 67, 1983, p. 34-35.
}

${ }^{80}$ p. 207. 
political $^{81}$. A different possible reading of embodiment, suggested by the previous remarks, would focus on its materiality as an instrument to shape and reproduce social order and organisation through the exercise of political power.

Foundations of Public Law hints at this material dimension ${ }^{82}$, but never develops the thread of subjectivity. In his Chorley lecture, Loughlin notes that the problem with the tradition of the material constitution is « the assumption that economic forces act on ideas in a purely causal fashion ${ }^{83} »$. While this remark might apply to certain forms of economic reductionism as presented, for example, in the works of Ferdinand Lassalle or Charles Beard $^{84}$, for whom the constitutional structure is just a reflex of undergirding economic power relations, it is certainly not applicable to more recent scholarship according to which the material constitution is a political construction whose requirements enable a relative autonomy of the political and are often confronted with a number of contradictions ${ }^{85}$.

A possible explanation of the relative absence of the role of subjects and their material conflicts in Foundations might be found in its historical reconstruction of the rise of the State's sovereignty. The lineage adopted by Loughlin is clear and privileges the type of modern political thought expressed in the philosophies of Bodin, Hobbes, Spinoza, Rousseau, and Hegel. The role of conflicts in right ordering is nonetheless present in the works attentive to questions linked to the salus rei publicae. One outstanding example is represented by Machiavelli, according to whom (and contrary to Hegel's influential interpretation of his work), at the origin of every order lies not a principle of political unity but always an inexhaustible conflict between antagonists ${ }^{86}$. Machiavelli sees a constitutive relation between order and conflict because the latter is immanent and it is intrinsic to reality. When he promises to follow «la verità effettuale delle cose » (the effective reality of things), he refers to the immanent space of conflict which

\footnotetext{
${ }^{81}$ It should be noted that Steinberger refers to the objectification of institutions, that is, the fact that they need to take a form in the material world: P. STEINBERGER, the Idea of the State, op. cit., p. 25.

${ }^{82}$ At page 208, Loughlin notes that « the material setting in which the idea of the state is set to work - the extent, location, and resources of the territory, and the customs and cultures of the peoples who comprise its members - not only have a significant impact on the ways in which the idea can be explicated, but will also re-shape the meaning of the idea itself » (p. 208).

${ }^{83}$ M. Loughlin, « The Constitutional Imagination », op. cit., p. 12.

${ }^{84}$ F. LASSAlle, Qu'est-ce qu'une constitution?, Paris, Dulliver, 1999; C. BEARD, An Economic Interpretation of the Constitution, New York, Dover Publications, 2004.

${ }^{85}$ Beyond Mortati and Poulantzas, an obvious example is represented by Antonio Gramsci (Prison Notebooks, New York, Columbia University Press, 2011) and, more recently, A. NEGRI, «Towards a Critique of the Material Constitution », in Books For Burning, London, Verso, 2005, p. 180-229; id. «On the Constitution and Financial Capital», Theory, 32, Culture \& Society, 2015, p. 25-38.

${ }^{86}$ N. Machiavelli, Discourses, ed. by B. Crick, London, Penguin, 1983. See F. DEL LUCCHESE, «Machiavelli and Constituent Power », European Journal of Political Theory, 2016, forthcoming.
} 
saturates the space of reality ${ }^{87}$. In Machiavelli's constitutional thought, collective subjects ( I grandi $»$ and «il populo ») and political forces are a quintessential staple in structuring the political constitution. It would be possible to trace the same methodological position through other modern political philosophers, although, in most cases, they would not belong to the tradition on which Loughlin builds ${ }^{88}$.

By avoiding the material dimension of the constitution, the risk is that the autonomy of the political will not be able to maintain the productive tension between polarities but will severe its internal relation with the social in favour of a transcendental relation. Only by focussing on the conflictual processes of subjectivation in the formation and maintenance of political unity is it possible, for political jurisprudence, to maintain the material dimension of public law as both visible and relevant. By including a material dimension, political jurisprudence would shed an additional, and different light on the governing art.

Marco Goldoni is Senior Lecturer at the Law School of the University of Glasgow; part-time researcher at CeLAPA (Centre for Law and Public Affairs) - Czech Academy of Sciences.

\footnotetext{
${ }^{87}$ N. MaChiAVELli, Il principe, Turin, Einaudi, 2002, p. 37. For analysis along these terms see M. VATTER, Between Form and Event. Machiavelli's Theory of Political Freedom, Deventer, Kluwer, 2000; cf. R. EsPOSITO, Living Thought: The Origins and Actuality of Italian Thought, Stanford, Stanford University Press, 2012, p. 41-54.

${ }^{88}$ For example, the young Marx wrote a draft of a strong criticism of Hegel's doctrine of public law which contains many important considerations for the critique developed in this article: K. MARX, Critique of Hegel's Doctrine of the State, in Early Writings, London, Penguin, 2005, p. 67-221; Cf. G. Della VolPE, Rousseau and Marx, London, Lawrence \& Wishart, 1978.
} 